

Working Paper n. 04 - 2015

\title{
AGAIN ON TRADE ELASTICITIES. EVIDENCE FROM A SELECTED SAMPLE OF COUNTRIES
}

\author{
Francesco Aiello \\ Dipartimento di Economia, \\ Statistica e Finanza \\ Università della Calabria \\ Ponte Pietro Bucci, Cubo 1/C \\ Tel.: +390984 492440 \\ Fax: +390984 492421 \\ e-mail: f.aiello@unical.it
}

\author{
Graziella Bonanno \\ Dipartimento di Economia, \\ Statistica e Finanza \\ Università della Calabria \\ Ponte Pietro Bucci, Cubo 0/C \\ Tel.: +390984 492474 \\ Fax: +390984 492421 \\ e-mail: graziella.bonanno@unical.it
}

\author{
Alessia Via \\ Liaison Office \\ Piazza Vermicelli, \\ Università della Calabria \\ Tel.: +390984 496938 \\ e-mail: alessia.via@unical.it
}

\section{Settembre 2015}

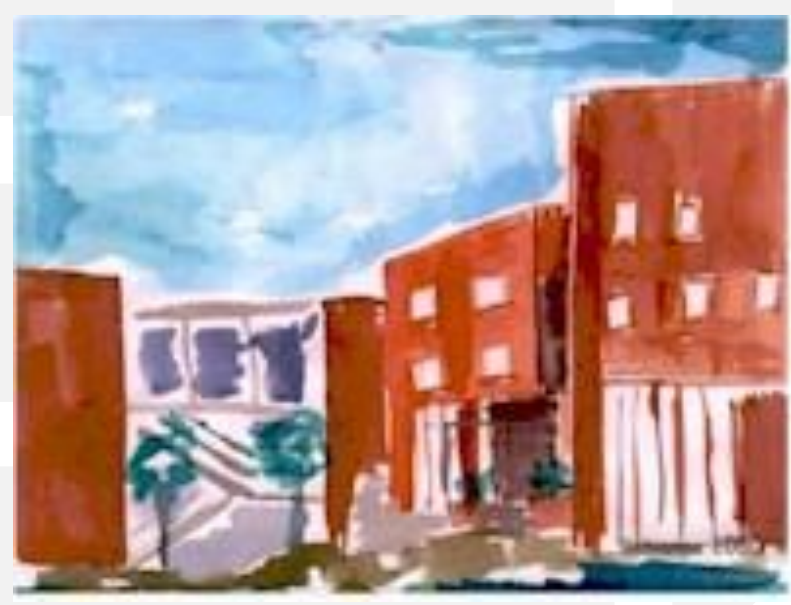




\title{
Again on trade elasticities. Evidence from a selected sample of countries
}

\author{
Francesco Aiello ${ }^{\mathrm{a}}$, Graziella Bonanno ${ }^{\mathrm{a}, \mathrm{b}}$, Alessia Via ${ }^{\mathrm{c}}$ \\ f.aiello@unical.it, graziella.bonanno@unical.it, alessia.via@unical.it \\ ${ }^{\text {a }}$ Department of Economics, Statistics and Finance, University of Calabria \\ I-87036, Arcavacata di Rende (CS), Italy \\ ${ }^{\mathrm{b}}$ Royal Docks Business School, University of East London, Docklands Campus \\ 4-6 University Way, London E16 2RD, UK \\ ${ }^{\mathrm{c}}$ Liaison Office, University of Calabria \\ I-87036, Arcavacata di Rende (CS), Italy
}

\begin{abstract}
This paper focuses on trade elasticities by analysing the case of China, France, Germany, Italy, Japan, UK, and the USA over the period 1990-2012. While the empirical setting mainly refers to panel data techniques for non-stationary data, the VECM model complements the analysis at single-country level. After having shown that long-run relationships are stable to any structural break, it is found that exports and imports are price inelastic for most of the countries in the sample. Furthermore, exports and imports are determined by domestic and foreign income, with asymmetric income elasticities. This helps to explain why global trade imbalances are persistent.
\end{abstract}

Keywords: trade elasticities, global trade imbalances; panel data JEL classification: C23, F10, F17, F37, P33

\section{Introduction}

Two main highly-correlated stylized facts are recurrent in international economics: one entailing instability in exchange rate markets, one involving global imbalances. Currency markets fluctuate a lot, at the time of its introduction in 1999, the exchange rate of $€ 1$ Euro was \$1.19 US dollar. Immediately later, the Euro experienced a downward trend that lasted two years. In the summer of 2001, its value had been reduced to a record low of 86 US cents. In 2014 the euro was appreciated with a peak of \$1.34 US dollar in March 2014. The fall of the euro against the dollar that has been observed during the first quarter of 2015 was the most rapid and protracted since the introduction of the EU currency. At the beginning of 2015, the dollar extended its gains against many of the world's major currencies (euro, sterling and yen) experiencing its strongest quarterly performance since 1992. Although the sterling is trading above $€ 1.40$ against the euro - its highest level since 2007 - it fell below $\$ 1.50$ against the dollar to its lowest level in 20 months. As expected, movements in currency markets anticipate imbalances in trade. The USA was a net exporter until 1975, when its trade surplus accounted for $1.07 \%$ of its GDP; it then experienced rapidly growing trade deficits and since the 1990s it has become the world's greatest debtor. In 2000 Germany had a trade deficit of $1.83 \%$ of its GDP; then, in few years, it became a net-exporter and by 2013 it had a trade surplus of $7.58 \%$ of its GDP. China ran a trade-surplus averaging $4.24 \%$ of its GDP from 1998 until 2013, peaking about 10\% in 2007.

These data highlight how important is the understanding of the macroeconomic determinants of trade flows. Of specific interest is comprehending whether trade flows are price-elastic. Again, it 
is noteworthy to verify whether the income elasticity asymmetry originally proposed by Houthakker and Magee (1969) persists in current data. Therefore, the key question becomes how much control in exchange rate markets is necessary to adjust trade imbalances. Indeed, with trade deficits a country uses foreign currencies to finance imports and domestic consumption. While borrowing from abroad is not a bad thing in itself, it may be a concern according to its size and persistence. Indeed, debts are to be repaid and foreigners may be worried about the ability of the net-importer to repay, thereby reducing lending or increasing the borrowing costs. If this is the case, there are strong incentives to depreciate the domestic currency relative to the others. In brief, the greater the trade deficits, the greater the depreciation and the greater the effect on domestic consumption due to the increase of import prices. Similar concerns arise from persistent trade surpluses, which force appreciation of the home currency. Additionally, sizable and persistent national trade surpluses in large economies generate global imbalances and tensions in world markets; indeed, there is serious concern over exporters managing their currency to gain from competitive devaluations. Disputes between national interests can turn into currency wars, when trading partners accuse each other of unfair practices in manipulating their exchange rates in order to boost exports and curb imports. ${ }^{1}$

In evaluating how trade balance evolves and reacts to market signals, one refers to the main factors determining trade flows, which are income and prices. More specifically, how much a country exports to other countries is determined by the foreign income and the relative price of domestic exports to the price of other goods that are available to consumers in foreign markets. Similarly, the most influential factors determining the amount of imports are the domestic income and the relative price of imported products to the goods internally produced. Within this framework of analysis, the prediction about trade balance can be made using trade elasticities, which measure how much the exports/imports of a country will vary in response to changes in income or relative prices. Thus the issue to provide reliable results on trade elasticities has been of general interest in the discipline since the seminal papers by Orcutt (1950), Houthakker and Magee (1969) and Kravis and Lipsey (1978).

Provided that trade imbalances and currency tensions are an issue, one would expect that controlling exchange rates is a feasible policy to improve trade balance. For instance, tensions in currency markets are understandable if devaluations lead to substantial increases in exports. In other words, exports are expected to be price-elastic. This expectation, however, is not empirically supported, as in many studies price-elasticity is less than unity. On the other hand, much empirics documents that long-run income elasticity of imports and exports diverge, thereby suggesting that, under certain conditions, global trade imbalances become permanent. The conclusion that can be drawn from this discussion is that exports are price-inelastic, whichever country and time period are examined and whatever the methods. Thus, macro-analyses do not make currency tensions easy to understand, because they originate from the controversial assumption of a high export price sensitivity. Indeed, if the macro-level estimates are reliable, then competitive devaluations will not lead to increased trade surpluses in the 'aggressive' countries and, therefore, will not penalize trading partners.

This paper contributes to the debate in three ways. Firstly, it proposes an updated analysis of the trade behaviour of six-OECD countries (France, Germany, Italy, Japan, the UK and the USA, henceforth the 6-OECDs) and China. The 6-OECDs have played a dominant role in international trade for some time, while China has become a big player since it joined the WTO in 2001. Trade is analyzed from 1990 to 2012, a period with a number of changes in world trade structures. Secondly, the analysis is carried out by using the panel unit root test proposed by Levin et al. (2002) and the

\footnotetext{
${ }^{1}$ Although the most prominent recent case is that of China, Germany, Japan and the UK have also manipulated their real exchange rates. Japan and the UK used quantitative easing in order to counter the current recession (Gagnon, 2013; Joyce et al. 2011), and, according to the U.S. Treasury, Germany's low level of investment and high savings rate contributed to the Eurozone crisis, which is characterised by increasing trade troubles for the EU periphery and huge surpluses for Germany.
} 
panel co-integration test of Westerlund (2007). Co-integration has been detected by referring also to the Johansen test (1991). Moreover, the Gregory-Hansen (1996) test is used for checking the structural stability. Structural breaks can affect model parameters, thereby inducing different policy implications. Thirdly, estimates of trade elasticities mainly refer to panel data techniques for nonstationary data. However, in order to check the robustness of panel-data results, the VECM model is also used to perform individual-country analyses. Trade equations come from the imperfect substitutes model proposed by Goldstein and Khan (1985). The use of panel data techniques is an important novelty because these methods are rarely used to estimate trade elasticities, although they were developed methodologically in the 1990s. After checking for non-stationarity, stability and cointegration of time-series, the analysis is carried out by applying the Pooled Mean Group estimator (PMG) developed by Pesaran, Shin and Smith (1999) and the Mean Group estimator (MG) of Pesaran, Smith and Im (1996), thus allowing for full country heterogeneity of short-run priceelasticity. Long-run elasticity is assumed to be common across countries in PMG and countryspecific in MG.

Results indicate that exports and imports depend on income growth, with long-run income elasticity higher than unity for China, Japan, Germany, the UK and the USA. Conversely, trade flows are price inelastic for most of the countries in the sample, both in the long- and in the shortrun. The exception is France, whose exports are price inelastic in the short-run and price elastic in the long-run. This result is robust to the estimation method. Interestingly, the values of income trade elasticities indicate that, other things being equal, the US trade deficit will be permanent and that Germany and China will continue to be net-exporters.

The paper is structured in 6 sections: Section 2 reviews the literature; Section 3 describes the data; Section 4 presents the tests for stationarity, co-integration and structural stability; Section 5 presents and discusses the estimates of trade elasticities; Section 6 concludes.

\section{Literature review}

In this strand of the literature, much research lies in the imperfect substitutes model formalized by Goldstein and Khan (1985), whose major assumption is that neither imports nor exports are perfect substitutes for domestic goods. ${ }^{2}$ This approach is motivated by the traditional partial equilibrium view of trade, where trade flows are a function of prices and income. Indeed, its main characteristics is based on the conventional demand theory, predicting that consumers maximize their utility subject to a budget constraint. Therefore, under the framework of imperfect substitutes, exports are determined by foreign income and price, while imports depend on domestic income and the relative price. After imposing trade balance, the econometric log-linear specification of exports and imports used in the related empirical literature is as follows: ${ }^{3}$

$$
\begin{aligned}
& \ln X_{i t}=\alpha_{i}+\beta_{1} \ln R E X_{i t}+\beta_{2} \ln Y_{t}^{w}+\mathrm{u}_{i t} \\
& \ln M_{i t}=\alpha_{i}+\beta_{3} \ln R E X_{i t}+\beta_{4} \ln Y_{i t}+\mathrm{u}_{i t}
\end{aligned}
$$

${ }^{2}$ Indeed, if domestic and foreign goods were perfect substitutes, then one should observe either the goods having a market share of unity, and each country acts as an importer or exporter of a traded good but not both (Goldstein and Khan 1985). Again, the coexistence of trade-flows and domestic production makes the hypothesis of perfect substitutes unrealistic.

${ }^{3}$ As the economic model from which the foreign demand originates is well-known, we omit to present the system of eight equations proposed by Goldstein and Khan (1985). In this we follow Hamori and Yin (2011), Ketenci and Uz (2011), Shigeyuki and Yoichi (2009), Caporale and Chui (1999), Senhadji and Montenegro (1999), Bahmani-Oskooee and Niroomand (1998), Sawyer and Sprinkle (1996), Thorbecke (2011). 
where $X_{i t}\left(M_{i t}\right)$ refers to the total national exports (imports) of country $i$ at time $t, R E X_{i t}$ is the relative price variable gauged by the Real EXchange rate of country $i$ at time t, $Y^{w}$ states for the world income, while $Y_{i}$ is the domestic income. Given the log-linear form of eq. (1) and (2), $\beta_{1}$ and $\beta_{3}$ are the exports and imports elasticity to the real exchange rate respectively, $\beta_{2}$ and $\beta_{4}$ are the exports and imports elasticity to income. Based on the theory, it is expected that $\beta_{1}$ is negative as a real depreciation results in higher competitiveness in world market, thereby inducing an increase of exports. Similarly, $\beta_{3}$ is expected to be positive as real depreciation causes an increase of import prices and, thus, determines a decrease of imports. The parameters $\beta_{2}$ and $\beta_{4}$ are expected positive, indicating that exports and imports rise with world and domestic income respectively.

The literature based on the models of the type outlined above is massive, with the initial influential papers by Orcutt (1950), Houthakker and Magee (1969) and Kravis and Lipsey (1978). The focus of each paper in this area of research ranges from estimating and discussing the estimated values of price elasticity and/or comparing the imports/exports income elasticity. Much pre-90s' literature is surveyed in Stern et al. (1976), Goldstein and Khan (1985) and Sawyer and Sprinkle (1996). Although these review papers demonstrate the wide range of price elasticities, here, it is noteworthy to observe that the picture does not change with more recent studies. Indeed, limiting the attention to price elasticities of aggregate trade-flows, several authors show that exports are price inelastic. Interestingly, this evidence holds up to country and time coverage, estimating techniques and other empirical choices of each primary paper (see, e.g., Algieri 2011; Anaraki 2014; Bayoumi et al. 2011; Chen et al. 2012; Crane et al. 2007; Dezeure and Teixeira 2014; Ketenci and Uz 2011; Thorbecke and Kato 2012; Yao et al. 2013). ${ }^{4}$ While this heterogeneity in the estimated values of export-price elasticity casts doubts on the effective size-effect of real devaluation, it also indicates that export price competitiveness remains a controversial and intriguing issue in international trade. In reviewing the literature, another important issue emerges when looking at results from export and import regressions. As already said, export equations yield heterogeneous, but rightly signed results, in the sense that a weaker national currency is associated with greater exports. The same does not always hold for imports. If exchange rate is expressed as the number of foreign currency units for domestic currency units, we expect that appreciating the domestic currency will yield an increase of imports. Actually, this theory-based expectation is not always fulfilled. The price sensitivity for imports has an incorrect sign in the study of Hooper et al. (1998) on US trade over the 1960-1994 period. Chinn (2004) focuses on US trade flows over the 1975-2003 period. He documents that aggregate US imports are difficult to model and finds little evidence of the long-run link between real exchange rates and imports. The price elasticity is even wrong-signed for US imports of computers and parts. Unexpected signs of import price elasticity are also found by Komoto and Thorbecke (2010) who analyze the trade flows of China, Japan,

${ }^{4}$ Algieri (2011) reports that the price elasticities of the exports of France, Italy, Japan, the Netherlands, Spain, the UK and the USA are rather small (in the range-0.3/0.8) over the period 1978-2009. Similarly, exports price-elasticity of Eurozone countries is low in Bayoumi et al. (2011) and in Chen et al. (2012) (0.6 and 0.46 respectively). Anaraki (2014) uses a Keynesian model and quarterly data over the 20012010 period and finds that a 10 per-cent Euro devaluation against the major currencies (yuan, dollar and yen) would increase the Eurozone's exports to China by 3.4 per-cent, to the USA by 2.4 per-cent and to Japan by 1.9 per-cent. Ketenci and Uz (2011) looked at the EU bilateral trade flows over 1980-2007 and found an export price-elasticity ranging in the $0.08 / 0.64$ interval. The price elasticity of German exports is 0.6 in Thorbecke and Kato (2012). Thorbecke and Kato (2012) focus on Japanese exports to 17 partners over the period 1988-2009 and find that exports are price inelastic, although a unitary long-run elasticity is found for consumption products. Crane et al. (2007) find that in the 1981-2006 period the price-elasticity is low for Italy (0.7), Japan (0.34) and the USA (0.6). Yao et al. (2013) looked at total Chinese exports from 1992 to 2006 and, even after controlling for an increase in product-variety, they find a short-run price-elasticity of 0.65 . Dezeure and Teixeira (2014) argue that in spite of depreciation of the pound, the weak growth of British exports in the 2000s is due to the virtually zero elasticity between exports and the exchange rate. 
Korea, Malaysia, Philippines and Thailand. An explanation is that "many of the imports into Asian countries are parts and components that are used to assemble goods for re-export to the rest of the world. An exchange rate appreciation in the assembly country that reduces exports will also reduce the demand for imported goods that are used to produce the exports" (Komoto and Thorbecke 2010:16).

From a methodological point of view, the early studies were essentially based on OLS, DOLS, and ARDL estimators. In the late 1990s, there was the co-integration analysis breakthrough, which was applied, for instance, by Bahmani-Oskooee and Niroomand (1998), Bahmani-Oskooee and Brooks (1999), Marquez (1999). Compared to the pre-existing works, the estimates provided by these studies lead to low values of price elasticity, but a certain heterogeneity remains, as long-run price elasticities vary from -0,02 for France's exports (Senhadji and Montenegro 1999), -0,27 for German exports (Anderton, 1991) to -3,13 for China's exports (Senhadji and Montenegro, 1999). An advance in the methods used to estimate import/export equations comes from the non-stationary panel data econometrics, which represents a source of new evidence in the field of trade elasticity. As is well-known, the power of panel-data methods for non-stationary time series is its attempt to combine the best of two worlds: the method of dealing with non-stationary data from the time series analysis and the increased data and power of cross-section analysis (Podestà, 2002; Hsiao, 2007; Baltagi, 2008; Bonham, 2013). As far as trade elasticity is concerned, the papers using these methods are relatively few. For instance, Roudet et al. (2007) investigate the long-run paths of real effective exchange rates of the seven African countries (Benin, Burkina Faso, Ivory Coast, Mali, Niger, Senegal and Togo) belonging to the West African Economic and Monetary Union (WAEMU). They employ both single-country and panel data co-integration techniques. By focusing on total imports and exports over the years 1970-2006, the authors find that the use of different estimation techniques leads to significant uncertainty about the path of real exchange rates equilibrium. Therefore, they conclude that "due to the uncertainty introduced by the different econometric techniques it is impossible to conclude that the real exchange rates in any WAEMU country is over/under-valuated" (p. 39). The conclusion is that "long-run equilibrium values would be model dependent; hence, it relies on the specification and set of fundamentals included in the analysis". Kubota (2009) assesses, over the 1970-2005 period, for a sample of 79 countries (21 industrial economies and 58 developing countries) whether exchange rate policies to foster growth through export promotion can sustain RER undervaluation. Both the ECM time series and the PMGE techniques report evidence on the existence of unit roots in the REER and its determinants and the presence of co-integration on both time-series and panel providing "an analytical framework to measure conceptually RER misalignment and conduct economic policy discussion more accurately. Béreau, S. et al. (2012) investigate the link between currency misalignments and economic growth. Relying on panel co-integration techniques, they calculate RER misalignments as deviations of actual RERs from their equilibrium values for a set of advanced and emerging economies $^{5}$ over the period 1980-2007. Using aggregate trade data, they show that RER misalignments have a differentiated impact on economic growth whereas RER under-evaluations can drive the exchange rate to a level that encourages exports and promotes growth. This result indicates that under-evaluations can drive the exchange rate to a level that encourages exports and promotes growth. Coşar (2012) estimates price and income elasticities of aggregate export demand presenting some panel unit root and co-integration tests for Italy, France, Germany, the UK, the Netherlands and the USA over the 1989-2000 period. According to the results, the RER elasticity of total export demand is found to be less than one, whereas the exports are income elastic. Finally, Jovanovic (2012) compares the aggregate and bilateral trade elasticities obtained from an ARDL

\footnotetext{
${ }^{5}$ Argentina, Australia, Brazil, Canada, Chile, China, Colombia, Costa Rica, Denmark, Egypt, the United Kingdom, Hong-Kong, Indonesia, India, Israel, Japan, Korea, Mexico, Malaysia, Norway, New Zealand, Peru, the Philippines, Singapore, Sweden, Switzerland, Thailand, Turkey, Uruguay, the United States, Venezuela and the Euro area.
} 
approach with those obtained using non stationary-panel techniques for Macedonia over the period 1998Q1-2011Q3. The estimates lead to the consideration that the nominal exchange rate worsens the trade balance in Macedonia rather than improving it.

This brief review highlights five points: first, the export-price elasticities are still too heterogeneous to yield consensus benchmark estimates; second, the prominent interest in export elasticities is due to the attempt to provide evidence on the competitive devaluation policies, in this respect, the understanding of the effectiveness of exchange rates manipulation is the main concern of many policy-oriented papers; third, the evidence on imports is not only more limited than that on exports, but results are often counterintuitive, thereby leaving open the question if and to what extent trade balance is sensitive to changes of real exchange rates; fourth, much research approximates the price competitiveness of imports and exports by referring to the real exchange rate, this procedure is correct only if the exports/imports elasticity to nominal exchange rate is equal to that of relative prices (home prices to foreign prices); finally, the joint analysis of imports and exports income and price elasticities is absent within the analytical framework of panel data, limiting the opportunity of understanding the relative effect on recent global trade imbalance determined by income growth and depreciating/appreciating policies. ${ }^{6}$

\section{Data and variables}

While the OECDs have always been important traders, China is the subject of interest in the current debate on exchange rate misalignments because of its growing role as an exporter. The sample of countries absorbs much of the world exports market, as their total export shares are around $47 \%$ in the 2-years 2000-2001 and about 43\% in 2012-2013 (Figure 1.a). From the imports side, the countries remain the largest importers in the world, as their cumulative share was $50 \%$ in 20002001 and 46\% in 2012-2013 (Figure 1.b) Data also highlight the impressive pattern of Chinese export shares, which increased by about seven percentage points, moving from $4.3 \%$ in 2001-2002 to $11.3 \%$ in 2012 . Interestingly, market shares have decreased for the other exporters (e.g. the USA market share was $8.6 \%$ in 2012 , but $11.9 \%$ in 2001), except for Germany, whose market share was $8 \%$ in 2012. What data clearly highlight is that China became an important exporter in few years. Panel B of Figure 1 points out that the USA is always the largest world importer, although its market share decreases by about 5 percentage points (from about $20 \%$ in 2000 to less than $15 \%$ in 2013). Data also highlight the positive trend of China as importer: in 2013 its market share was $11 \%$ of world imports. The pattern of German import share is regular, floating around the annual average of $8 \%$. No specific dynamics can be ascribed to Italy, Japan, France and the UK, whose market shares are quite stable. Figure 1.4 highlights the different trend of trade balance relative to GDP in every country. Some countries (USA, UK) observe a trade imbalance over the period 20002013, while others (China, Germany) have a systematic trade surplus. The increasing trend of German trade surplus, the declining trend of France and Japan after 2004, the U-shape pattern of the UK trade deficit over the most recent years and the reversed U-shape Chinese surplus centred in 2007 are also interesting issues.

\footnotetext{
${ }^{6}$ According to the Houthakker and Magee (1969), if growth is uniform across country and the relative prices of imports/exports remain constant over time, then an economy will experience a permanent trade deficit, provided that the income elasticity of imports is higher than that of exports. If the asymmetry of income elasticities persists, then long-run trade balance can be assured only by large home currency devaluation. This line of research has received much attention in the past, proving that the asymmetry is robust across time periods, countries and econometric methods (see. e.g., Chinn 2004; Crane et al. 2007; Hooper et al 2000). However, it disappears for services and, thus, might attenuate at national level when countries will trade more in services than in manufacturing (Mann 2002; Wren-Lewis and Driver 1998).
} 
Figure 2 plots the time-series of exports, imports and real exchange rates over the 1990-2012 period $(2005=100){ }^{7}$ Although a strong positive increase is revealed for the exports in each country, the highest increase refers to China, followed by the UK and the USA. Another common result is the drop of trade at the time of the 2008 financial crisis. Exports reduced much more in Italy and Japan than in other countries. All countries observed a recovery of exports and imports after 2008. Moreover, Figure 2 clearly highlights that exports and imports exhibit a non-stationary pattern. The same does not appear for the real exchange rate, which is a fact that deserves more statistical attention (see $\S 4$ ). In the case of REX, there is much more instability along the trend than a strict trend pace itself. Hence, it becomes interesting to evaluate the effects of this variability on export behaviour. It is an issue that will be addressed in the following paragraphs when measuring the short-run relationship trade-price-elasticity. In brief, looking at Figures 1 and 2 one learns that the trade equations must be specified in order to take into account the long-run pattern of each time series and the varying dynamics of real exchange rate.

Figure 1

Dynamics of world market shares and trade balance by country in 2000-2013 (2005=100)

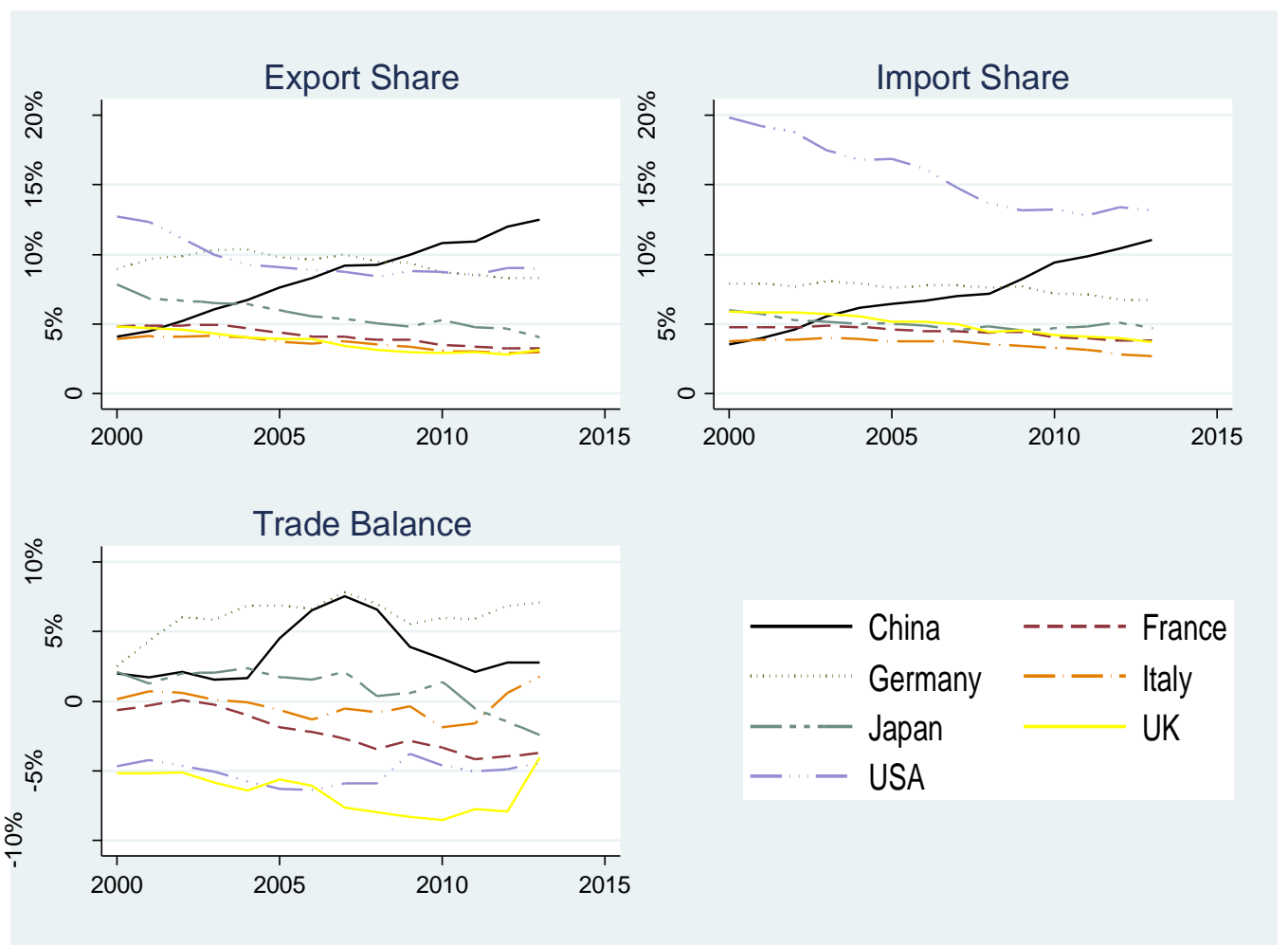

${ }^{7}$ For each country, the real exchange rates is constructed as the trade-weighted average exchange rate of a currency against a basket of currencies after adjusting for inflation differentials with regard to the countries concerned.. It is based on the Consumer Price Index (CPI), thus, in formula we have this general expression $R E X_{i, t}=C P I_{i t} / C P I_{R o W, t} \times E_{i t}$, where the nominal exchange rate $E_{i t}$ is the domestic currency price of one unit of foreign currency. For countries with the same currency, i.e. EU countries, the differences in REER collapse to differences in domestic prices. 
Figure 2

Dynamics of total exports, imports and REX by country from 1990 to 2013
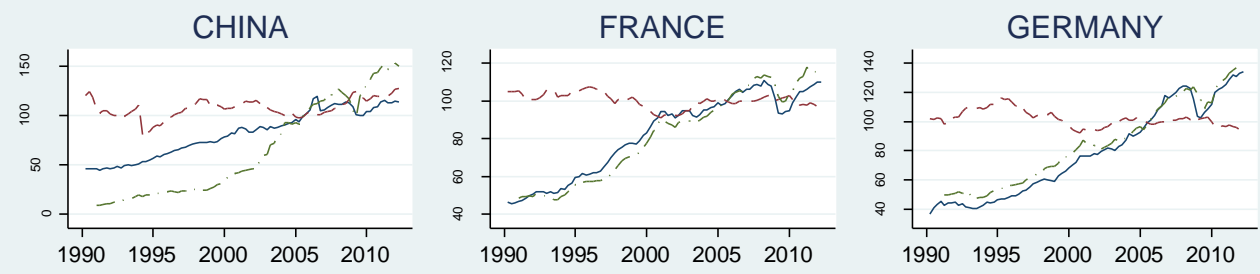

ITALY

JAPAN

UK


USA

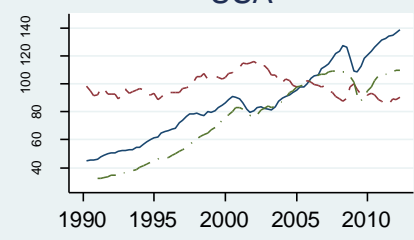

Source: elaborations on data from Datastream.

Legend:- Exports;-- Imports;-- REX

\section{Testing stationarity, co-integration and structural stability}

In order to detect the stochastic properties of time-series, we use the Levin, Lin and Chu (2002) panel unit root test (LLC). This test fits for homogeneous panel and assumes that each individual unit shares the same AR(1) coefficient, but allows for individual and time effects. Lags of the dependent variable are introduced to allow for serial correlation. The test is a pooled Dickey-Fuller test, or an ADF test when lags are included, with the null hypothesis of non-stationarity. The $t$ statistic converges to the standard normal distribution. The period under scrutiny is from 1990:Q1 to 2012:Q1. Data are from Datastream and are expressed on a quarterly basis. They are in real terms (2005 is the base-year) and seasonally adjusted. Table 1 shows the results. 
Regarding exports, the estimated coefficient of the one-period lagged variable is -0.03 and the LLC test supports the hypothesis of non-stationarity with a high level of significance (the pvalue is about 0.82 ). Evidence against stationarity also holds for the imports side (in this case the pvalue is 0.97 ). These tests corroborate what we have deduced when looking at Figure 2: exports and imports are not stationary. The same applies for the real exchange rate, as the coefficient of the oneperiod lagged variable is -0.07 (the p-value is 0.19 ) and for home income (the one-period lagged variable is 0.02 with a p-value of 1$).^{8}$

Table 1

Levin Lin Chu test for exports, imports, GDP and REX time-series

\begin{tabular}{|c|c|c|}
\hline Exports & & \\
\hline \multirow[t]{3}{*}{ Pooled ADF test (1 lag) } & $N, T=(7,89)$ & Obs $=609$ \\
\hline & Coefficient & -0.031 \\
\hline & p-value & 0.8167 \\
\hline \multicolumn{3}{|l|}{ Real exchange rate } \\
\hline \multirow[t]{3}{*}{ Pooled ADF test (1 lag) } & $N, T=(7,89)$ & Obs $=609$ \\
\hline & Coefficient & -0.069 \\
\hline & p-value & 0.1860 \\
\hline \multicolumn{3}{|l|}{ Imports } \\
\hline \multirow[t]{3}{*}{ Pooled ADF test (1 lag) } & $N, T=(7,73)^{*}$ & Obs $=497$ \\
\hline & Coefficient & -0.011 \\
\hline & p-value & 0.9703 \\
\hline \multicolumn{3}{|l|}{ Home Income (GDP) } \\
\hline \multirow[t]{3}{*}{ Pooled ADF test ( 1 lag) } & $N, T=(7,73)^{*}$ & Obs $=497$ \\
\hline & Coefficient & 0.0202 \\
\hline & p-value & 1.0000 \\
\hline
\end{tabular}

Source: see Figure 1

* Note: LLC test requires that the panel must be balanced, thus the test is conducted for 73 periods (not 89), as data of Japanese GDP and imports start from 1994.

After non-stationarity has been ascertained, the next step is to verify the existence of any cointegrating process. The longitudinal nature of the dataset suggests the co-integration should be tested by following Westerlund (2007) test, whose rejection of $\mathrm{H}_{0}$ should be taken as rejection of

${ }^{8}$ World income $\left(\mathrm{Y}^{\mathrm{w}}\right)$ is also non-stationary. This comes from the augmented Dickey-Fuller test (1981). The statistic-test is the tau-test $(\tau)$, as tabulated by MacKinnon (2010). The estimated coefficient of $\mathrm{Y}^{\mathrm{w}}$ is -3.03 with a p-value=0.12 Furthermore, the evidence of table 1 overlaps that obtained when performing the ADF-t test for heterogeneous panels as proposed by Im et. al (2003) (results are available upon request). It is also important to emphasize that our panel is composed of a sectional dimension of seven exporters. This issue belongs to the long-dated discussion comparing large to small panel data (Eberhardt 2011). It can be addressed by performing robustness analyses as made in, e.g., Roudet et al.(2007). In our case, the large T dimension should ensure the reliability of panel data results. However, we find that panel data estimations for exports overlap a lot of those obtained from the individualcountry study, while they differ from VECM evidence as far as imports are concerned ( $c f r$. Table 5). 
co-integration for the entire panel. The underlying idea is to test for the absence of co-integration by determining whether the individual time-series follow an error correction model. The test is very flexible and allows for an almost completely heterogeneous specification of both the long-run equilibrium and the short-run dynamics. For exports, results show that the $\mathrm{H}_{0}$ of no co-integration in the panel is rejected, implying that there is a significant co-integrating relationship between exports and $\mathrm{Y}^{\mathrm{w}}$ and REX: the $\mathrm{z}$-statistics is -7.353 with a p-value of zero. For imports, the Westerlund (2007) test fails to reject the Ho. As this result contrasts with the evidence emerging from Figures 1 and 2, we proceed by detecting co-integration by applying the Johansen (1991) test at singlecountry level. Results suggest that moving from a panel to an individual country analysis yields evidence about the co-integration behaviour among imports, home income and real exchange rates, whatever the country. ${ }^{9}$

The analysis carried out so far disregards possible structural breaks in the co-integration relationship between exports/imports and real exchange rate. A break may be the result of global shocks, governmental policies, institutional reforms and other country-specific factors. If the break is significant, it alters the co-integration parameters, thereby undermining the estimation of any cointegrating-vector. Therefore, after accepting the hypothesis of stability more can be learned about the structural links between exports/imports and real exchange rate, in the sense that the long-run relationship will be seen as reliable.

The existence of structural breaks was detected with the Gregory and Hansen (1996) test (hereafter $\mathrm{GH}$ ), which considers co-integration processes allowing intercepts and/or slope coefficients to break at an unknown time-point. Formulas for exports $(\mathrm{Xt})$ are as follows:

$\ln X_{t}=\mu_{1}+\mu_{2} \varphi_{t \tau}+\beta \ln R E X_{t}+\mathrm{u}_{t}$
$\ln X_{t}=\mu_{1}+\mu_{2} \varphi_{t \tau}+\delta \mathrm{T}+\beta \ln R E X_{t}+\mathrm{u}_{t}$
$\ln X_{t}=\mu_{1}+\mu_{2} \varphi_{t \tau}+\delta \mathrm{T}+\beta \ln R E X_{t}+\beta \ln R E X_{t} \varphi_{t \tau}+\mathrm{u}_{t}$

where $\varphi_{t \tau}$ is the dummy variable

$\varphi_{t \tau}=\left\{\begin{array}{l}0 \text { if } t \leq[n \tau] \\ 1 \text { if } t>[n \tau]\end{array}\right.$

The parameter $\tau \in(0,1)$ denotes the timing of the break point (the regime shift) and $[n \tau]$ is the integer part, where $n$ is the number of periods in the analysis. In eq. [3], the break is modelled as a change in the intercept. If a break occurs at time $t$, the intercept is $\mu_{1}$ before $t$ and $\mu_{1}+\mu_{2}$ after $\mathrm{t}$. As it allows for a level shift in the long-run relationship and is known as "level shift model". In eq. [4] a time trend is added to the eq. [3], yielding a "level shift with trend model". Finally, the "regime shift model" allows for breaks to slope vector (eq. 5). The same applies for import (M) equation, replacing $\mathrm{X}$ with $\mathrm{M}$ on the left-right side of eq. [3]-[5].

The GH test identifies potential breaks in the long-run relationship between exports/imports and real exchange rates. The null hypothesis is the absence of change in the long-run relationship. Under the alternative hypothesis there is a pace towards a new long-run equilibrium. The test is an extension of the ADF, $Z_{t}$ and $Z_{\mathrm{a}}$ test-statistics for co-integration and, therefore, allows us to detect

\footnotetext{
${ }^{9}$ In what follows we report the Johansen test, country-by-country. The cointegration rank is 1 for Italy (pvalue: 0.25), Japan (p-value: 0.38), France (p-value: 0.78), China (p-value: 0.07), UK (p-value: 0.61), Germany (p-value: 0.88$)$, USA (p-value: 0.38$)$.
} 
the stability of co-integration in the presence of structural change. ${ }^{10}$ Table 2 shows the results for exports, while Table 3 refers to imports. As can been seen from Table 2, several break points are identified, but few of them determine significant changes in the export price elasticities before and after the break. The significant breaks are revealed only by the regime shift model and refer to France (at $1 \%$ level of significance), and China and the UK (at the 5\% level of significance) (Table 3). ${ }^{11}$ Regarding the other exporters, we see that the three statistics tests (ADF, $Z_{t}$ and $Z_{a}$ ) converge to the same decision. Table 3 displays the results of the $\mathrm{GH}$ test for imports, highlighting the existence of some structural breaks in every country. However, none of them are so significant as to change the long-run relationship between imports and real exchange rates, which results stable over time.

The GH test is also highly informative about the time of the break. A break is detected for China at the $52^{\text {nd }}$ period that corresponds to the first quarter of 2003 when the test is run with ADF. The break is identified at the $46^{\text {th }}$ period (third quarter of 2001) if the test is implemented through $Z_{a}$ and $\mathrm{Z}_{\mathrm{t}}$. The 2001 accession to WTO and that of Chinese Taipei in 2002 may be the reasons of these breakpoints (Kerr and Hobbs, 2001). This shock, however, was not strong enough to affect the long-run export-price elasticity. Interestingly, in testing for changes in the constant, a break is identified for Italy in 1993 ( $13^{\text {th }}$ period with Z-statistics and $15^{\text {th }}$ with ADF): the GH test captures some shocks arising from the 1992 devaluation of the national currency adopted to stimulate exports (Macis and Schivardi, 2012). Even in this case the long-run path of Italian exports is robust to the break. Results from eq. [4] are qualitatively similar to those obtained with the first test, while, as already said, eq. [5] indicates that some significant breaks occurred for France, China and the UK. In particular, the findings show that the long-run elasticity does not change before and after the structural breaks. Regarding the breakpoint time, the evidence indicates that Germany faced a break in 2004. This might be related to the so-called Hartz act, that is, the labor market reforms introduced in Germany in 2003-2005 (Bodegan et al., 2010; Jacobi and Kluve, 2006). Furthermore, a break is detected for China, France, Italy and UK in 2008 (Table 2), that is, when some shocks due to the financial crisis started with the US sub-prime loans and propagated worldwide (Grigor'ev and Salikhov, 2009). The GH test fails to capture any remarkable circumstance in the USA in 2008. Conversely, the USA exhibited a structural change during the last quarter of 2001 (Table 2, third test), surely due to the World Trade Center terrorist attack and to the dot.com crisis (Abadie and Gardeazabal, 2003). Thus, we can argue that the revealed 2001 break is more important than that related to the expected effect of the 2008 crisis; however, is not important enough to affect significantly the long-run path of US exports.

${ }^{10}$ The starting point to calculate $Z_{a}$ and $Z_{t}$ statistics is to estimate the first-order serial correlation coefficient, $\hat{\rho}^{*}$ of OLS residuals. The difference between $Z_{a}$ and $Z_{t}$ consists in the fact that $Z_{t}$ consider also a transformation of the long-run variance $\hat{s}^{2}$ of OLS residuals (in formulas: $Z_{a}(\tau)=n\left(\hat{\rho}_{\tau}{ }^{*}-1\right)$ and $\left.Z_{t}(\tau)=\left(\hat{\rho}_{\tau}{ }^{*}-1\right) / \hat{s}\right)$. The $A D F(\tau)$ statistic is calculated by regressing OLS residuals (in first-differences) against their lags and the lagged first-differences. The statistics $\mathrm{ADF}, \mathrm{Z}_{\mathrm{a}}$ and $\mathrm{Z}_{\mathrm{t}}$ are calculated across all estimated values of the regime shifts $\tau \in \mathrm{T}$. Then, the GH test is performed by taking the smallest values of each statistics, as they constitute evidence against the null hypothesis. The test-statistics become $Z_{a}=\inf _{\tau \in \mathrm{T}} Z_{a}(\tau), Z_{t}=\inf _{\tau \in \mathrm{T}} Z_{t}(\tau)$ and $A D F=\inf _{\tau \in \mathrm{T}} A D F(\tau)$.).

${ }^{11}$ In the econometric estimations of exports model we control for these breaks in the co-integration vectors of France, China and the UK. To this end, we augment the regressions by allowing for differences in slopes after 2008. However, results do not change. This is likely because the value of the calculated statistics is slightly smaller than the critical value (Table 2), suggesting that the breaks that the GH tests reveal are not strong enough to induce any structural change in the co-integration vectors. 
Table 2

Gregory-Hansen test for co-integration for exports

Level shift model

Level shift with time trend
Regime shift model

Test Statistic Breakpoint date Test Statistic Breakpoint date Test Statistic Breakpoint date

\begin{tabular}{|c|c|c|c|c|c|c|c|c|c|}
\hline China & & & & & & & & & \\
\hline ADF & -3.20 & 52 & 2003: Q1 & -3.27 & 52 & 2003: Q1 & $-5.16^{* *}$ & 74 & 2008: Q3 \\
\hline $\mathrm{Zt}$ & -3.13 & 46 & 2001: Q3 & -3.17 & 46 & 2001: Q3 & $-5.04 * *$ & 74 & 2008: Q3 \\
\hline $\mathrm{Za}$ & -13.26 & 46 & 2001: Q3 & -13.26 & 46 & 2001: Q3 & -36.98 & 74 & 2008: Q3 \\
\hline \multicolumn{10}{|c|}{ France } \\
\hline ADF & -3.19 & 55 & 2003: Q4 & -3.19 & 59 & 2004: Q4 & $-5.94 * * *$ & 73 & 2008: Q2 \\
\hline $\mathrm{Zt}$ & -3.40 & 54 & 2003: Q3 & -3.42 & 36 & 1999: Q1 & $-5.64 * * *$ & 74 & 2008: Q3 \\
\hline $\mathrm{Za}$ & -17.25 & 54 & 2003: Q3 & -16.45 & 36 & 1999: Q1 & -44.95 & 74 & 2008: Q3 \\
\hline \multicolumn{10}{|c|}{ Germany } \\
\hline ADF & -3.28 & 58 & 2004: Q3 & -3.31 & 58 & 2004: Q3 & -4.63 & 58 & 2004: Q3 \\
\hline $\mathrm{Zt}$ & -3.66 & 57 & 2004: Q2 & -3.74 & 53 & 2003: Q2 & -4.50 & 59 & 2004: Q4 \\
\hline Za & -17.63 & 57 & 2004: Q2 & -17.95 & 53 & 2003: Q2 & -24.64 & 59 & 2004: Q4 \\
\hline \multicolumn{10}{|l|}{ Italy } \\
\hline ADF & -3.23 & 15 & 1993:Q4 & -4.22 & 32 & 1998:Q1 & -4.27 & 73 & 2008: Q2 \\
\hline $\mathrm{Zt}$ & -3.41 & 13 & 1993:Q2 & -4.26 & 35 & 1998:Q4 & -4.48 & 73 & 2008: Q2 \\
\hline $\mathrm{Za}$ & -18.09 & 13 & 1993:Q2 & -19.49 & 35 & 1998:Q4 & -23.43 & 73 & 2008: Q2 \\
\hline \multicolumn{10}{|c|}{ Japan } \\
\hline ADF & -3.54 & 59 & 2004: Q4 & -3.60 & 31 & 1997: Q4 & -4.94 & 59 & 2004: Q4 \\
\hline $\mathrm{Zt}$ & -3.70 & 53 & 2003: Q2 & -3.44 & 33 & 1998: Q2 & -4.98 & 57 & 2004: Q2 \\
\hline Za & -18.75 & 53 & 2003: Q2 & -18.29 & 33 & 1998: Q2 & -31.08 & 57 & 2004: Q2 \\
\hline \multicolumn{10}{|l|}{ UK } \\
\hline ADF & -3.46 & 70 & 2007: Q3 & -3.45 & 71 & 2007: Q4 & $-5.17^{* *}$ & 74 & 2008: Q3 \\
\hline $\mathrm{Zt}$ & -3.05 & 66 & 2006: Q3 & -2.86 & 74 & 2008: Q3 & $-5.09 * *$ & 75 & 2008: Q4 \\
\hline Za & -13.74 & 66 & 2006: Q3 & -12.35 & 74 & 2008: Q3 & -36.38 & 75 & 2008: Q4 \\
\hline \multicolumn{10}{|l|}{ USA } \\
\hline ADF & -3.58 & 29 & 1997: Q2 & -4.07 & 57 & 2004: Q2 & -4.51 & 48 & 2002: Q1 \\
\hline $\mathrm{Zt}$ & -3.86 & 29 & 1997: Q2 & -4.24 & 58 & 2004: Q3 & -4.56 & 47 & 2001: Q4 \\
\hline $\mathrm{Za}$ & -26.25 & 29 & 1997: Q2 & -23.44 & 58 & 2004: Q3 & -25.81 & 47 & 2001: Q4 \\
\hline
\end{tabular}

N. of periods: 89 .

Note: $* * * 1 \%$ significant; ${ }^{* *} 5 \%$ significant. The asymptotic critical values for the level shift model at $1 \%$ and $5 \%$ are, respectively, -5.13 and -4.61 for ADF and Zt statistics; -50.07 and -40.48 for Za statistic. The asymptotic critical values for the level shift model with time trend at $1 \%$ and $5 \%$ are, respectively, -5.47 and -4.95 for ADF and Zt statistics; 57.17 and -47.04 for Za statistic. The asymptotic critical values for the regime shift model at $1 \%$ and $5 \%$ are, respectively, -5.45 and -4.99 for ADF and Zt statistics; -57.28 and -47.96 for Za statistic. 
Table 3

Gregory-Hansen test for co-integration for imports

Level shift model
Level shift with time trend
Regime shift model

\begin{tabular}{|c|c|c|c|c|c|c|c|c|c|}
\hline China & Test Statistic & \multicolumn{2}{|c|}{ Breakpoint date } & Test Statistic & \multicolumn{2}{|c|}{ Breakpoint date } & Test Statistic & \multicolumn{2}{|c|}{ Breakpoint date } \\
\hline ADF & -3.74 & 50 & 2002: Q3 & -4.11 & 49 & 2002: Q2 & -3.52 & 16 & 1994: Q1 \\
\hline $\mathrm{Zt}$ & -4.04 & 51 & 2002: Q4 & -4.29 & 49 & 2002: Q2 & -4.19 & 14 & 1993: Q3 \\
\hline $\mathrm{Za}$ & -24.62 & 51 & 2002: Q4 & -25.92 & 49 & 2002: Q2 & -25.17 & 14 & 1993: Q3 \\
\hline \multicolumn{10}{|c|}{ France } \\
\hline ADF & -4.09 & 52 & 2003: Q1 & -4.11 & 53 & 2003: Q2 & -4.25 & 34 & 1998: Q3 \\
\hline $\mathrm{Zt}$ & -3.91 & 51 & 2002: Q4 & -3.91 & 52 & 2003: Q1 & -4.59 & 51 & 2002: Q4 \\
\hline $\mathrm{Za}$ & -22.07 & 51 & 2002: Q4 & -21.50 & 52 & 2003: Q1 & -22.30 & 51 & 2002: Q4 \\
\hline \multicolumn{10}{|c|}{ Germany } \\
\hline ADF & -3.67 & 57 & 2004: Q2 & -3.72 & 57 & 2004: Q2 & $-5.57 * * *$ & 58 & 2004: Q3 \\
\hline $\mathrm{Zt}$ & -3.89 & 56 & 2004: Q1 & -3.94 & 56 & 2004: Q1 & -4.53 & 57 & 2004: Q2 \\
\hline $\mathrm{Za}$ & -18.95 & 56 & 2004: Q1 & -19.23 & 56 & 2004: Q1 & -26.24 & 57 & 2004: Q2 \\
\hline \multicolumn{10}{|l|}{ Italy } \\
\hline ADF & -2.28 & 50 & 2002: Q3 & -3.26 & 28 & 1997: Q1 & -4.35 & 27 & 1996: Q4 \\
\hline $\mathrm{Zt}$ & -2.62 & 49 & 2002: Q2 & -2.88 & 30 & 1997: Q3 & -3.71 & 72 & 2008: Q1 \\
\hline $\mathrm{Za}$ & -11.44 & 49 & 2002: Q2 & -13.75 & 30 & 1997: Q3 & -21.92 & 72 & 2008: Q1 \\
\hline \multicolumn{10}{|c|}{ Japan } \\
\hline ADF & -3.46 & 29 & 1997: Q2 & -3.81 & 60 & 2005: Q1 & -4.83 & 56 & 2004: Q1 \\
\hline $\mathrm{Zt}$ & -3.45 & 37 & 1999: Q2 & -3.58 & 60 & 2005: Q1 & -4.10 & 59 & 2004: Q4 \\
\hline $\mathrm{Za}$ & -18.69 & 37 & 1999: Q2 & -22.99 & 60 & 2005: Q1 & -23.16 & 59 & 2004: Q4 \\
\hline \multicolumn{10}{|l|}{ UK } \\
\hline ADF & -3.50 & 64 & 2006: Q1 & -3.54 & 54 & 2003: Q3 & -4.60 & 72 & 2008: Q1 \\
\hline $\mathrm{Zt}$ & -3.50 & 71 & 2007: Q4 & -3.55 & 51 & 2002: Q4 & -4.82 & 72 & 2008: Q1 \\
\hline Za & -15.29 & 71 & 2007: Q4 & -14.99 & 51 & 2002: Q4 & -35.65 & 72 & 2008: Q1 \\
\hline \multicolumn{10}{|l|}{ USA } \\
\hline ADF & -4.10 & 56 & 2004: Q1 & -4.47 & 51 & 2002: Q4 & -4.77 & 70 & 2007: Q3 \\
\hline $\mathrm{Zt}$ & -3.84 & 30 & 1997: Q3 & -3.97 & 36 & 1999: Q1 & -4.62 & 71 & 2007: Q4 \\
\hline $\mathrm{Za}$ & -21.10 & 30 & 1997: Q3 & -24.46 & 36 & 1999: Q1 & -28.85 & 71 & 2007: Q4 \\
\hline
\end{tabular}

N. of periods: 73 for Japan; 85 for Germany and Italy; 86 for China, France, the UK and the USA.

Note: ${ }^{* *} 1 \%$ significant; ${ }^{* *} 5 \%$ significant. The asymptotic critical values for the level shift model at $1 \%$ and $5 \%$ are, respectively, -5.13 and -4.61 for ADF and Zt statistics; -50.07 and -40.48 for Za statistic. The asymptotic critical values for the level shift model with time trend at $1 \%$ and $5 \%$ are, respectively, -5.47 and -4.95 for ADF and Zt statistics; 57.17 and -47.04 for $Z a$ statistic. The asymptotic critical values for the regime shift model at $1 \%$ and $5 \%$ are, respectively, -5.45 and -4.99 for ADF and Zt statistics; -57.28 and -47.96 for Za statistic. 


\section{Estimations of trade elasticities}

\subsection{Econometric setting}

Having found that there is a co-integrating relationship and that it is stable over time, we proceed by estimating equations [1] and [2] with panel-data techniques for non-stationary and co-integrated time-series. In this respect and after introducing dynamics and an error correction mechanism, the estimation of eq. [1] and [2] was made by performing the Pooled Mean Group estimator (PMG) proposed by Pesaran et al. (1999) and the Mean Group estimator (MG) of Pesaran et al. (1996). Both approaches address the non-stationarity of time-series for heterogeneous panels.

Generally speaking, an econometric specification of trade flows allows for different degrees of parameter heterogeneity across countries. At one extreme, the full heterogeneity imposes no cross-country parameter restrictions. As the period of each time-series is large enough, the mean of long- and short-run coefficients across countries can be estimated consistently by the un-weighted average of any individual coefficient estimated at country level. This is done by the MG method. At the other extreme, the fully homogeneous coefficient model requires that all slopes and intercepts be equal across countries. ${ }^{12}$ This is the simple "pooled" estimator. In 'between these two extremes' there is the PMG method, which restricts the long-run coefficients to being the same across countries, but allows the short-run coefficients and the speed of adjustment to be country-specific. The PMG also generates consistent estimates of the mean of short-run coefficients across countries by taking the un-weighted average of the individual country coefficients (given that the crosssectional dimension is large). In $I(1)$ panels this estimator "allows for mix of co-integration and no co-integration" (Eberhardt, 2011). ${ }^{13}$

Exports regression based on eq. [1] and aligned to the PMG framework is as follows:

$\Delta \log X_{i, t}=\delta i+\beta_{1 i} \Delta \log R E X_{i, t}+\lambda_{l i}\left(\theta_{1} R E X_{i, t-1},-X_{i, t-1}\right)+\beta_{2 i} \Delta \log Y_{i, t}^{w}+\lambda_{2 i}\left(\theta_{2} Y_{i, t-1}^{w},-X_{i, t-1}\right)+v_{i, t}$

with $\mathrm{v}_{\mathrm{it}} \sim$ iidN $\left(0, \sigma_{\mathrm{i}}{ }^{2}\right)$ and $(\mathrm{i}=1, . ., 7 ; \mathrm{t}=1, . ., 89)$. The MG specification differ from the PMG only for what concerns the long-run parameters $\theta_{1}$ and $\theta_{2}$, which, in the MG method, vary across countries. In other words, the subscript $i$ is inserted in $\theta_{1}$ and $\theta_{2}$, consistently with the hypothesis of countryspecific long-run equilibrium, that is: ${ }^{14}$

$\Delta \log X_{i, t}=\delta_{i}+\beta_{1 i} \Delta \log R E X_{i, t}+\lambda_{1 i}\left(\theta_{1 i} R E X_{i, t-l},-X_{i, t-1}\right)+\beta_{2 i} \Delta \log Y_{i, t}^{w}+\lambda_{2 i}\left(\theta_{2 i} Y_{i, t-1}^{w},-X_{i, t-l}\right)+\mathrm{v}_{i, t}$

Similarly, the PMG and MG econometric specifications of imports model (eq. [2]) are the following:

$\Delta \log M_{i, t}=\delta i+\beta_{1 i} \Delta \log R E X_{i, t}+\lambda_{1 i}\left(\theta_{l} R E X_{i, t-1},-M_{i, t-1}\right)+\beta_{2 i} \Delta \log Y_{i, t}+\lambda_{2 i}\left(\theta_{2} Y_{i, t-1},-M_{i, t-1}\right)+v_{i, t}$

12 They are basically the traditional pooled estimators (fixed and random effects estimators), where the intercepts differ across groups while the other coefficients and error variances are constrained to be the same (Pesaran et al. 1996).

${ }^{13}$ Both MG and PMG offer a good compromise between consistency and efficiency. The PMG is useful if countries share the determinants of steady-state, whereas the short-run adjustment are related to country characteristics. In other words, the PMG predicts a common long-run equilibrium relationship and shortrun dynamics of each country. In brief, MG always yields consistent estimates, whilst PMG results are consistent and efficient only if the hypothesis of common long-run elasticity is empirically accepted (Pesaran et al. 1996; Pesaran et al. 1999).

${ }^{14}$ The PMG estimator is quite appealing when studying small sets of arguably 'similar' countries rather than heterogeneous panels (Eberhardt, 2011). The requirements for the validity of both these methods are such that: $(i)$ there is a long-run relationship among the variables of interest and, (ii) the dynamic specification be augmented such that the regressors are exogenous and the residuals are serially uncorrelated. Finally, this analytical framework does not control for cross-country common factor effects. This issue is left for future work. 
$\Delta \log M_{i, t}=\delta_{i}+\beta_{I i} \Delta \log R E X_{i, t}+\lambda_{I i}\left(\theta_{l i} R E X_{i, t-1},-M_{i, t-1}\right)+\beta_{2 i} \Delta \log Y_{i, t}+\lambda_{2 i}\left(\theta_{2 i} Y_{i, t-1},-M_{i, t-1}\right)+\mathrm{v}_{i, t}$

In order to control for non-stationarity, the variables in eq. [6]-[9] are in first differences, as they are non-stationary in level. ${ }^{15}$ The coefficients $\beta_{i}$ are short-run parameters which, like $\sigma_{\mathrm{i}}{ }^{2}$, differ across countries. The error-correcting speed of adjustment term $\lambda_{i}$ also differs across $i$. The long-run parameters $\theta_{i 1}$ and $\theta_{i 2}$ differ country-by-country for MG. As said, short-run country heterogeneity is allowed in both estimators, while long-run elasticities differ country by country in the MG framework and are common across countries in the PMG. However, in using the MG it is also possible to collapse short- and long-run elasticities to their average values. The same applies in the PMG regarding the short-run dynamics. For ease of exposition, in what follows the discussion distinguishes between the evidence regarding the entire panel $(\S 5.2)$ and that obtained at level of individual country $(\S 5.3)$. A brief discussion and some explanations of the results are in sub-section 5.4 .

\subsection{Results for the whole panel}

The estimated values of trade elasticities for the panel as a whole are summarized in Table 5 . Looking at the results for exports, all the elasticities have the expected sign and are highly significant. The evidence is two-fold. On the one hand, exports are income-elastic in the long-run. Indeed, the income elasticity is higher than 1 both when using the PMG and the MG model, even though the magnitude of the effect differs: exports are more income-elastic when considering the MG instead of the PMG approach. A shock of $1 \%$ in world demand would determine an increase of exports of $1.08 \%$ under PMG and $1.39 \%$ under MG (Table 4). However, it is meaningful to point out that 1.08 is not statistically different than 1 and thus it is possible to argue that, under PMG, exports have a unitary income elasticity. Differently, the averaged long-run income elasticity in MG is statistically different than $1 .{ }^{16}$ Our estimates reveal that the income sensitivity of exports is even higher in the short-run, 3.8 being the average of the elasticities in PMG as well as in the MG model. A world income shock of $1 \%$ induces an increase of $3.8 \%$ in exports in the short-run. Turning to price-elasticity, table 6 indicates that the demand of exports of all countries, as a whole, is priceinelastic, whatever the model. Long-run price-elasticity is -0.89 in PMG and -0.86 as far as the MG estimator is concerned (the value from MG is the average of the elasticities predicted country by country). In both the cases, exports are inelastic, even though the estimated elasticities are not significantly less than unity. ${ }^{17}$ The low price sensitivity becomes even more noticeable in the shortrun: the elasticity ranges from -0.11 in the case of MG model to -0.17 under PMG. Based on these results we can argue that if countries adopt competitive devaluation policies the effect would be an increase in their total national exports, but not so large as to be considered aggressive in the world market equilibrium. The evidence demonstrates that a real devaluation of $10 \%$ (as averaged across all countries in the sample) would induce an increase in exports of $8.6 \%$ in the long-run and of, at best $1.7 \%$, in the short-run. Passing to imports, we find less encouraging results than exports ones. Under the PMG model, the import elasticities are both significant, but price elasticity is wrong signed (-0.56), whereas income has the expected positive value, although the elasticity is low, that is 0.55. The signs of PMG import elasticities are confirmed in the short run, but the statistical significance is weak. The results obtained for imports when using the MG estimator are also unintelligible. To the same extent, estimations displayed in table 4 can be seen as an indication that panel data procedure is not suitable for modeling the imports of the sample of countries covered in the study. This is coherent with the abovementioned Westerlund (2007) test ( $c f r$. § 4), which failed

\footnotetext{
${ }^{15}$ The MG offers the opportunity to obtain only one short-run and long-run elasticity simply by averaging the estimations of each individual country.

${ }^{16}$ For PMG we accept the null hypothesis of unitary elasticity (the test-statistic is 1.58 with p-value of 0.21 ), while for MG estimations we reject the null hypothesis as the test-statistic is 8.50 (pvalue $=0.0035$ ).

${ }^{17}$ For PMG the test-statistic is 0.66 (p-value $=0.42$ ), while for MG it is 0.22 (p-value=0.64).
} 
to detect co-integration in the panel of imports when actually there are long-run relationships at single country level (as disclosed by results from the Johansen (1991) test that are summarized in footnote 9).

Table 4

Estimation of export and import functions of China and 6-OECDs.

PMG and MG averaged estimations over the period 1990-2012

\begin{tabular}{|c|c|c|c|c|}
\hline \multirow{3}{*}{ PMG Estim } & \multicolumn{2}{|c|}{ Exports } & \multicolumn{2}{|c|}{ Imports } \\
\hline & & & & \\
\hline & Coef. & $\mathrm{P}>|\mathrm{z}|$ & Coef. & $\mathrm{P}>|\mathrm{z}|$ \\
\hline \multicolumn{5}{|l|}{ Long-run } \\
\hline $\ln (\mathrm{REX})$ & -0.8906 & 0.000 & -0.5688 & 0.035 \\
\hline In(Income) & 1.0813 & 0.000 & 0.5479 & 0.002 \\
\hline
\end{tabular}

Short-run

\begin{tabular}{lrrrr} 
Error correction term & -0.0703 & 0.000 & -0.0292 & 0.069 \\
$\Delta \ln ($ REX) & -0.1734 & 0.003 & -0.1986 & 0.187 \\
$\Delta \ln$ (Income) & 3.8339 & 0.000 & 0.4614 & 0.113 \\
Intercept & 0.2422 & 0.000 & 0.1403 & 0.056 \\
\hline
\end{tabular}

MG Estimations

\begin{tabular}{lcccc}
\hline & Coef. & $P>|z|$ & Coef. & $P>|z|$ \\
\hline Long-run & & & & \\
$\ln ($ REX) & -0.8663 & 0.002 & -2.2865 & 0.102 \\
$\ln$ (Income) & 1.3935 & 0.000 & -0.6293 & 0.662 \\
\hline
\end{tabular}

\begin{tabular}{|c|c|c|c|c|}
\hline Short-run & & & & \\
\hline Error correction term & -0.1467 & 0.000 & -0.0452 & 0.010 \\
\hline$\Delta \ln (\mathrm{REX})$ & -0.1136 & 0.093 & -0.1800 & 0.238 \\
\hline$\Delta \ln ($ Income $)$ & 3.8236 & 0.000 & 0.4561 & 0.110 \\
\hline Intercept & 0.0848 & 0.601 & 0.1843 & 0.317 \\
\hline
\end{tabular}




\subsection{Results at single country level}

From the above discussion regarding import models, it is clear that the empirical strategy to use panel data estimators must be complemented by an analysis at individual country level. To this end we refer to a VECM model, which, in the case of exports, may be seen as a robustness test of panel data evidence, while it assumes a more important role as far as imports are concerned. It is noteworthy to emphasize that the joint use of panel and single-country analyses is not a novelty in this field of research (see, e.g., Roudet et al. 2007). Table 5 presents the long-run trade elasticities obtained with the VECM and the MG estimators. ${ }^{18}$

Table 5

Long-run elasticities of exports and imports. MG and VECM estimations

\begin{tabular}{|c|c|c|c|c|c|c|c|c|}
\hline & \multicolumn{4}{|c|}{ Exports } & \multicolumn{4}{|c|}{ Imports } \\
\hline & \multicolumn{2}{|c|}{ MG } & \multicolumn{2}{|c|}{ VECM } & \multicolumn{2}{|c|}{ MG } & \multicolumn{2}{|c|}{ VECM } \\
\hline & 1 & 2 & 3 & 4 & 5 & 6 & 7 & 8 \\
\hline & $\begin{array}{c}\text { Price } \\
\text { Elasticity }\end{array}$ & $\begin{array}{l}\text { Income } \\
\text { Elasticity }\end{array}$ & $\begin{array}{c}\text { Price } \\
\text { Elasticity }\end{array}$ & $\begin{array}{l}\text { Income } \\
\text { Elasticity }\end{array}$ & $\begin{array}{c}\text { Price } \\
\text { Elasticity }\end{array}$ & $\begin{array}{l}\text { Income } \\
\text { Elasticity }\end{array}$ & $\begin{array}{c}\text { Price } \\
\text { Elasticity }\end{array}$ & $\begin{array}{c}\text { Income } \\
\text { Elasticity }\end{array}$ \\
\hline China & $-0.22^{\wedge}$ & 1.55 & $-0.22^{\wedge}$ & 1.45 & $-0.39^{\wedge}$ & $0.35^{\wedge}$ & 2.05 & 1.07 \\
\hline France & -2.04 & 1.01 & -1.41 & 1.00 & $-6.20^{\wedge}$ & $-9.05^{\wedge}$ & $5.9^{\wedge}$ & 1.41 \\
\hline Germany & -0.67 & 2.03 & $-0.02^{\wedge}$ & 2.23 & -4.68 & 1.36 & 0.25 & $1.8^{\wedge \wedge}$ \\
\hline Italy & -0.72 & 0.98 & -0.72 & 1.01 & $-7.14^{\wedge}$ & $0.81^{\wedge}$ & $0.4^{\wedge}$ & 1.27 \\
\hline Japan & -0.52 & 1.36 & -0.55 & 1.34 & $-0.48^{\wedge}$ & 0.67 & 0.65 & 1.25 \\
\hline Uk & $-0.11^{\wedge}$ & 1.47 & -0.83 & 1.60 & $2.61^{\wedge}$ & $0.68^{\wedge}$ & $-0.37^{\wedge}$ & 1.03 \\
\hline USA & -1.77 & 1.35 & -2.42 & 1.20 & $0.27^{\wedge}$ & 2.21 & 0.2 & 2.05 \\
\hline
\end{tabular}

Legend: statistical significance is $5 \%$ if not otherwise reported; ${ }^{\wedge}$ not significant; ${ }^{\wedge} \wedge$ significant at $10 \%$.

First of all, it is fruitful to point out that the aggregate export function is, as expected, foreign income $\left(Y^{w}\right)$ elastic. From MG results, we already know that the average long-run income elasticity is equal to 1.39 (Table 4). However this value disregards high country heterogeneity (Tables 5, A1 and A2). Indeed, foreign income results to be very effective for Germany (the estimated elasticity is 2.03), China (1.55), the UK (1.46), Japan (1.36) and the USA (1.35). France and Italy exhibit a unitary income elasticity of exports. ${ }^{19}$ Furthermore, we reveal significant differences in the values of export price-elasticity. This holds true in the long- and in the short-run. In the long-run, the

${ }^{18}$ From the exports side, it becomes important to verify which is the best performing model between MG and PMG. To this end we ran an LR test. The two models are nested in each other: the PMG is the restricted model, while the MG is without restrictions. The long-run elasticities are common across countries under the $\mathrm{H}_{0}$ hypothesis, while the alternative is that they differ from one country to another (as assumed by the MG estimator). According to LR results, we reject the null hypothesis: the LR yields a chi2 $(12)=44.0$ with a $p$-value $=0$. This means that the assumption that countries share the same equilibrium is unrealistic and not supported by data. On the contrary, we find that each country converges to its own long-run equilibrium. Based on this, our discussion then focuses only on the price and income elasticities estimated through the MG method (Tables 4 and A2), while the PMG evidence is reported in the appendix Table A1.

${ }^{19}$ Income is even more important in the short-run. Indeed, if a positive shock of $1 \%$ in world income occurred, then exports would increase, in the short-run, by $6.94 \%$ in Japan, $4.06 \%$ in Italy, 3.9\% in the UK, about 3\% in China, France and Germany and by $2.6 \%$ in the USA. Furthermore, the short-run analysis reinforces the low sensitivity of exports to prices, as a significant relationship between exports and REX has been estimated only for Italy (-0.33), France (-0.25), UK (-0.23) and USA (-0.19) (Appendix Tables A1 and A2). 
analyzed countries have, as expected, a statistically significant negative coefficient with respect to the real exchange rate $(R E X)$. Estimates vary from -0.52 (Japan) to -2.04 (France). Between these two values we find that the export price-elasticity is -0.72 for Italy and -0.67 for Germany. The result regarding China and the UK is negative, but not significant, since their exports are independent of price in the long-run. The USA exports exhibit a high $(-1.77 \%)$ long-run priceelasticity, although the statistical significance is just $13 \%$. In brief, we find that exports from six out of seven countries of the sample are price-inelastic, with the exception of France, whose exports would increase by $2 \%$ in the presence of a real depreciation of $1 \%$. For the other countries, real devaluation would induce an increase in exports but less than the relative change in national currency. Is it noteworthy to point out that when considering the exports model, the sign and the statistical significance of each parameter does not vary when moving from MG to VECM models. Interestingly, even the magnitude of export elasticities is very similar. This contrasts with the evidence proved by Roudet et al. (2007), as their estimations are very sensitive to the estimation methods. In our case, the similarity in results is in favor of panel-data estimations over individual time-series as the former have the advantage to come from a common analytical framework, thereby assuring a faithful comparability across countries.

The picture significantly varies when referring to imports. We have already learnt that PMG and MG results for the panel as a whole are unsatisfactory (Table 4). This is confirmed when looking at the country-by-country evidence (columns 5 an 6 of Table 5). Price elasticities are not significant, except for German imports, whose elasticity appears pointless (the sign is wrong and the magnitude is implausible). On the contrary, VECM performs better. Indeed, imports price-elasticity is positive and significantly different than zero for China, Germany, Japan, and the USA. Imports of France, Italy and the UK appear to be unrelated to the real exchange rate. When the price elasticity is significant, it signals, for instance, that Chinese imports are highly responsive to real changes of home currency: a 10\% depreciation of the yuan would imply a $20 \%$ reduction of national imports. A similar $10 \%$ shock of home currency real value, would have a lower impact on German imports (they would reduce by $2.5 \%$ ), Japan (6.5\%) and the USA $(2.1 \%)$. Regarding the role of home income, the VECM results indicate that the imports are income-elastic, confirming the high dependence of imports on domestic factors. Imports income elasticity ranges from 1.17, that is the estimated value for China, to 2.05 for US. Germany and UK observe high values (1.8 and 1.77 respectively) of home income elasticity of their national imports (Table 5).

\subsection{Discussion}

This section synthesizes the results and complements the discussion by referring to additional data. What we have estimated from exports side is that, over the 1990-2012 period, Chinese exports are real exchange rate insensitive both in the long- and in the short-run. The same applies for the UK in the long-run. The long-run price-elasticity of the USA exports is high, but not strongly significant. In the remaining cases, exports are price-inelastic. The only exception is France, whose exports are price-elastic in the long-run and price-inelastic in the short-run. However, the finding that France performs differently than other exporters is not a novelty in this strand of literature. For instance, in Crane et al. (2007) the price-elasticity of France is 2.9 , which is a high value compared to the values estimated in that work for Italy (0.7) and the USA (0.6). In Borey and Quille (2013) France also registers the highest value (1.1) of price-elasticity (for the UK and Germany it is 0.5 and 0.1 respectively). As this mixed evidence reflects differences in the countries' export-structure, discerning the causes of "low-high" real exchange rates elasticity deserves further research based on a different model specification and on highly disaggregated trade-flows aimed at capturing the sectorial and geographic positioning and the quality ranges of each exporter. Here, a few explanations are proposed by looking at some data at the macro-level. Table 6 displays some trade statistics of each exporter (we maximize the data-availability of each source, whose time-coverage differs from each other). The first fact to highlight regards the capital goods that have fewer close substitutes than other products and, therefore, are less sensitive to price: a low proportion of exports 
of capital-goods is expected to be associated with high price-elasticity. The results satisfy the expectations, as the correlation between the estimated long-run elasticity and the share of capital goods is 0.64. Importantly, among our sample, France registers the highest long-run price-elasticity and the lowest $(11 \%)$ proportion of capital-goods exported. Conversely, the highest proportion $(22 \%)$ of capital-goods is found in China, whose exports are price-inelastic. Similarly, services are more differentiated than goods. Then a high proportion of services in exports should be associated with low price-elasticity. The contrary holds for food, which tends to be more homogeneous than other goods: hence, the higher the food in exports the higher the price-elasticity. In our case, priceelasticity is wrongly correlated with services in exports, while the correlation between priceelasticity and food in exports is high and, as expected, positive (0.75). Interestingly, at countrylevel, the peak (13\%) of the proportion of food in exports regards France, which is the country with the highest estimated value of export price-elasticity. Finally, we find that market destination matters in understanding cross-country differences in export elasticity: in such a case the correlation with the share of exports to high-income countries is positive (albeit it is not high and decreases from 0.23 in 1990-91 to 0.19 in 2011-12). These facts emphasize the role of capital goods and food in exports and, at the same time, suggest that the explanation of heterogeneity in price-elasticity requires a more detailed study on the country specialization than the discussion we present here and a deep-analysis of exports quality.

Furthermore, some interesting insights come from a joint reading of exports and imports results. Although import estimations are frankly puzzling, and hence solicit prudency in their interpretation, the use of VECM allows some comparisons. For instance, Table 5 suggests that the asymmetry between exports and import income elasticity is recurrent. According to VECM results, the US will experience a trade deficit, as well as Italy, France Japan and the UK. On the other hand, the VECM analysis carried out in this study allows argument that China and Germany tend to a long-run equilibrium which is characterized by a permanent trade surplus. Put in other words, without any shock to international price competitiveness, the trade income elasticities estimated for China and Germany are large enough to render the current trade imbalances stable over time that the data highlight (cfr. Figure 1.c)

Finally, the contrasting results of imports price-elasticity deserve further analysis surely entailing specific-country factors in the vein of the suggestions already made for exports. Additionally, as far as the trade model specification is concerned, it is remarkable to say that this study is based on the real exchange rates, whose use is motivated by the assumption that the relative prices and the nominal exchange rates exert the same impact on trade flows. While this is common in this strand of the literature, the interpretation of trade elasticities would benefit from decomposing the real exchange rate (REX) into its two components, that is, the nominal exchange rate (NEX) and the relative prices of imports and exports. In this regard, some descriptive and valuable signals come from Figure 3, which plots the time series of REX, NEX and an index of domestic prices relative to foreign prices. ${ }^{20}$ The results demonstrate that the relative prices have a constant declining trend for every country, except for China. Regarding the exchange rates, one may observe that the time-series of real exchange rates faithfully overlap those of nominal exchange rates in Italy and UK. This also holds for France, Germany, Japan and the USA after 1997-1998, whereas before that date the real exchange rates were higher/lower than the nominal exchange rates. The difference between the real and nominal exchange rate of the Chinese yuan is much higher, in particular before China joined the WTO in 2001. The pattern of these trade determinants differs

${ }^{20}$ As for REX, for each reporting country the nominal effective exchange rate it is weighted through by the respective trade shares of each partner (cf. footnote 7). Data needed to calculate the relative import/export prices are from OECD. The relative price is the ratio between two index prices $(1995=100)$, that is, the home index consumer price of each trader and the foreign index consumer price. As there are no index prices for the all trade-partners, the foreign prices are those calculated by OECD for all members. Here, the assumption is that OECDs, as a whole, is a good proxy of world market, both from import and export sides of every country in the sample. 
greatly across country and over time, allowing for further consideration in order to understand empirically whether and to what extent this variability translates to different import/export priceelasticities. This is an issue to be addressed in future work.

Table 6

Exports price elasticity and countries export structure

\begin{tabular}{|c|c|c|c|c|c|c|c|c|}
\hline \multirow[t]{2}{*}{ Country } & \multirow{2}{*}{$\begin{array}{l}\text { Long-run } \\
\text { exports price } \\
\text { elasticity (MG) }\end{array}$} & \multirow{2}{*}{$\begin{array}{l}\text { Exports of } \\
\text { capital goods as } \\
\% \text { of total } \\
\text { exports } \\
\text { (1995-2012) (1) }\end{array}$} & \multicolumn{2}{|c|}{$\begin{array}{c}\text { Proportion of } \\
\text { services in exports } \\
\text { (2) }\end{array}$} & \multicolumn{2}{|c|}{$\begin{array}{l}\text { Proportion of food } \\
\text { in exports }(2 ; 3)\end{array}$} & \multicolumn{2}{|c|}{$\begin{array}{c}\text { Exports to high- } \\
\text { income economies } \\
\text { (\% of total exports) } \\
\text { (2) }\end{array}$} \\
\hline & & & 2005 & 2012 & 2012 & $\begin{array}{l}1990- \\
2012\end{array}$ & $1990-91$ & 2011-12 \\
\hline China & $-0.22^{\wedge}$ & 22 & 12 & 9 & 3 & 6 & 86 & 75 \\
\hline France & -2.04 & 11 & 21 & 27 & 13 & 13 & 84 & 80 \\
\hline Germany & -0.67 & 17 & 15 & 15 & 5 & 5 & 87 & 81 \\
\hline Italy & -0.72 & 15 & 20 & 17 & 8 & 7 & 85 & 78 \\
\hline Japan & -0.52 & 19 & 15 & 15 & 1 & 1 & 79 & 59 \\
\hline UK & $-0,11^{\wedge}$ & 15 & 35 & 38 & 6 & 6 & 89 & 83 \\
\hline USA & $-1.77^{*}$ & 16 & 29 & 30 & 10 & 9 & 75 & 61 \\
\hline
\end{tabular}

Note ${ }^{\wedge}=$ not-significant: ${ }^{*}$ p(value $)=0.135$

(1) Data are from Comtrade (2-digit code "41" of BEC classification);

(2) Data are from World DataBank (World Development Indicators 2015);

(3) Food and live animals, beverages and tobacco, animal and vegetable oils and fats.

Figure 3. Dynamics of nominal exchange rates, real exchange rates and relative prices by country from 1990 to 2012 (2005=100)
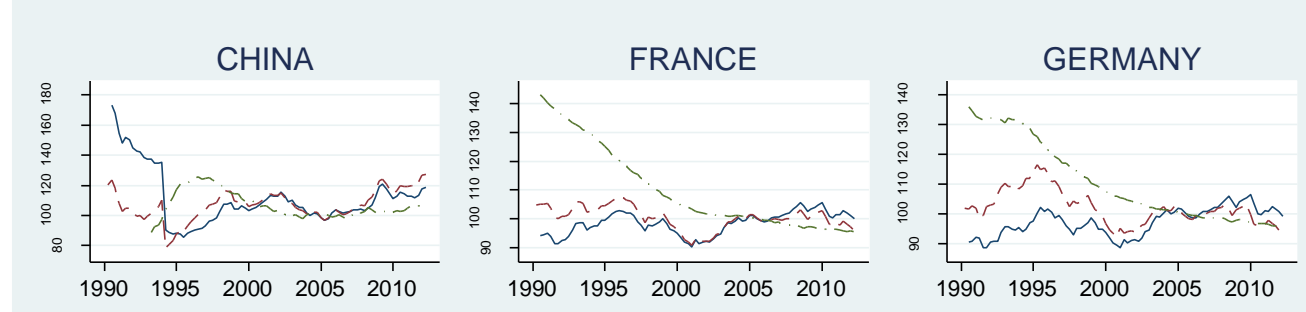

ITALY

JAPAN

UK
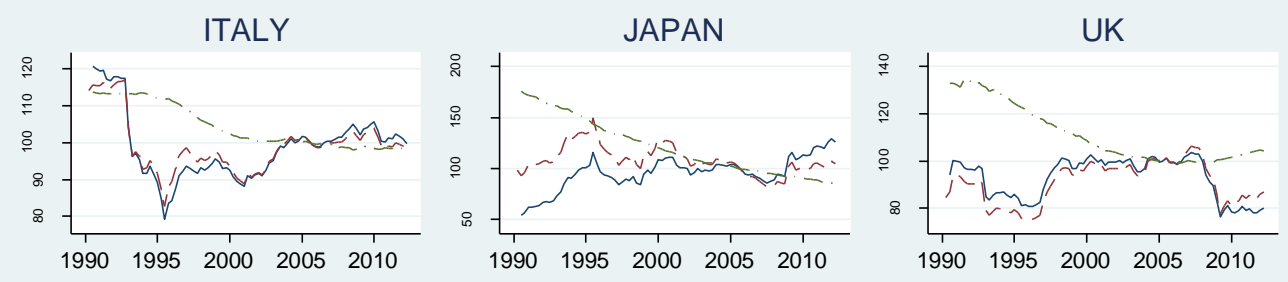

USA



Legend: - NEX; --- REX; -.- Relative Price 


\section{Concluding remarks}

This paper estimates the trade elasticities of seven countries (China, France, Germany, Italy, Japan, the UK, and the USA) over the period 1990-2012. The analysis is based on the economic model proposed by Goldstein and Khan (1985), while the econometric setting refers to panel data models for non-stationary and co-integrated time series, that is the PMG and the MG estimators. These methods, however, are well performing only for export equations, whereas they yield unsatisfactory results for imports. Hence, we report convincing evidence that for the sample of countries and the period covered in this study, the analysis of import flows receives many benefits from using individual country analysis rather than the panel data setting. Thereof, PMG and MG results are complemented by VECM estimations. On the one hand, we find that VECM estimates overlap those from panel data estimates for exports, suggesting that export elasticities are robust to the estimating method. On the other hand, interpretable import elasticities are provided only by VECM.

From an economic perspective, exports and imports are, on average, price-inelastic. As far as the seven countries are concerned, MG long-run exports price-elasticity is -0.89 , meaning that exports would increase by $8.9 \%$ after a $10 \%$ depreciation of exchange rate. In other words, total exports increase in cases of competitive devaluation policies, but far less than the expansions one expects after having observed how severe the tensions on currency markets are. The low export price sensitivity holds true when focusing on individual countries. Surprisingly, the nexus exportsprice competitiveness is difficult to interpret in the case of China, whose long-run price-elasticity is low and not significant and in the short-run is also signed wrongly (although again not significant). Similarly, the long-run level of exports appears to be unrelated to the real exchange rate for the UK. When results are significant, the long-run price-elasticity is less than unity for Japan, Germany and Italy. The exception is France, whose exports exhibit a long-run elasticity of -2, whilst its exports are price-inelastic in the short-run. A similar high long-run price-elasticity is found for the USA, albeit it is weakly significant. Imports are price-elastic only for China, and price-inelastic for Germany, Japan and the USA. The analysis does not yield conclusive evidence on imports price elasticity of France, Italy and the UK. Noticeably, these outcomes are robust over time, as there is no significant change in the long-run co-integrated path of exports and real exchange rates, even after having identified some structural country-level breaks at specific points of time.

This mixed evidence supports the pessimistic view that exchange rate policies may not be fully successful in promoting trade flows: if a competitive devaluation is carried out by aggressive countries, total exports will in fact increase, but only moderately and imports will decrease, but weakly. This is puzzling, especially in the light of the debate on currency imbalances which assumes that trade flows are highly price-elastic. On the contrary, our findings suggest that devaluation gains are less than expected, because aggregate exports are price-inelastic. This particularly holds true for China, as we find that the demand of importing countries rather than the price of exported goods plays a crucial role in boosting Chinese exports. We also report some evidence that this country is changing its export structure, from food and low-technology products to trade in mid-technology goods. If this process to gain position in the global value chain is stable over time, then the advantages that China would gain from updating the technological contents in exports will be less dependent on price than in the past.

Additionally, we find that the aggregate trade flows are highly income elastic, implying that increases in aggregate demand positively affect the total trade flows of China and of the 6-OECDs considered in the study. This result is consistent with the expectations. The VECM evidence indicates that the estimated values of imports income elasticity differs from that related to exports, signalling the persistence of the asymmetry revealed by Houthakker and Magee (1969). This implies that, ceteris paribus, the trade imbalance could be a "rule" rather than an "exception". Indeed, other things being fixed, some countries (in primis the USA) will experience trade deficits, while others, that is China and Germany, will maintain the current status of net exporters. In brief, if global trade balance is a policy-target to be pursued, then there will be room for a large depreciation of the US dollar, or appreciation of the yuan and the euro. 
Table A1

Estimations of the export function of China and 6-OECDs

Results from Pooled Mean Group Estimator (1990:Q1-2012:Q1)

\begin{tabular}{|c|c|c|c|}
\hline \multicolumn{4}{|l|}{ Long-Run } \\
\hline $\ln (\operatorname{REX})$ & $-0.8906 * * *$ & & \\
\hline $\ln \left(Y^{w}\right)$ & $1.0813^{* * *}$ & & \\
\hline China, Short-Run & & Japan, Short-Run & \\
\hline Error correction term & $-0.0345^{*}$ & Error correction term & $-0.1516 * * *$ \\
\hline $\begin{array}{l}\Delta \ln (\text { REX) } \\
\Delta \ln \left(Y^{\mathrm{w}}\right)\end{array}$ & $\begin{array}{l}0.0371 \\
2.9605^{* * *}\end{array}$ & $\begin{array}{l}\Delta \ln (R E X) \\
\Delta \ln \left(Y^{w}\right)\end{array}$ & $\begin{array}{l}0.0482 \\
7.1225 * * *\end{array}$ \\
\hline Intercept & $0.1176^{*}$ & Intercept & $0.5184 * * *$ \\
\hline \multicolumn{2}{|l|}{ France, Short-Run } & \multicolumn{2}{|l|}{ UK, Short-Run } \\
\hline Error correction term & $-0.0648 * * *$ & Error correction term & $-0.0365^{* *}$ \\
\hline$\Delta \ln (\mathrm{REX})$ & $-0.3225 * *$ & $\Delta \ln (\mathrm{REX})$ & $-0.2337 * *$ \\
\hline$\Delta \ln \left(Y^{w}\right)$ & $3.0207^{* * *}$ & $\Delta \ln \left(Y^{\mathrm{w}}\right)$ & $4.0029 * * *$ \\
\hline Intercept & $0.2251^{* *}$ & Intercept & $0.1130 *$ \\
\hline \multicolumn{2}{|l|}{ Germany, Short-Run } & \multicolumn{2}{|l|}{ USA, Short-Run } \\
\hline Error correction term & -0.0280 & Error correction term & $-0.0469 * * *$ \\
\hline$\Delta \ln (R E X)$ & -0.1888 & $\Delta \ln (\mathrm{REX})$ & $-0.2282 * *$ \\
\hline$\Delta \ln \left(Y^{w}\right)$ & $3.2094 * * *$ & $\Delta \ln \left(Y^{\mathrm{w}}\right)$ & $2.5566 * * *$ \\
\hline Intercept & 0.0935 & Intercept & $0.1672 * * *$ \\
\hline \multicolumn{4}{|l|}{ Italy, Short-Run } \\
\hline Error correction term & $-0.1297 * * *$ & & \\
\hline$\Delta \ln (\mathrm{REX})$ & $-0.3261^{* * *}$ & & \\
\hline$\Delta \ln \left(\mathrm{Y}^{\mathrm{w}}\right)$ & $3.9644 * * *$ & & \\
\hline Intercept & $0.4606 * *$ & & \\
\hline
\end{tabular}

Obs $=616$; Number of Groups $=7$; Obs. per Group $=88$

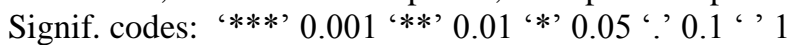


Table A2

Estimations of the export function of China and 6-OECDs Results from Mean Group Estimator (1990:Q1-2012:Q1)

\begin{tabular}{|c|c|c|c|}
\hline China & & Japan & \\
\hline Long-Run & & Long-Run & \\
\hline $\ln (\mathrm{REX})$ & -0.2207 & $\ln (\mathrm{REX})$ & $-0.5254 * * *$ \\
\hline $\ln \left(Y^{w}\right)$ & $1.5546 * * *$ & $\ln \left(Y^{w}\right)$ & $1.3637 * * *$ \\
\hline Short-Run & & Short-Run & \\
\hline Error correction term & $-0.1175^{* *}$ & Error correction term & $-0.2331 * * *$ \\
\hline$\Delta \ln (\mathrm{REX})$ & 0.0430 & $\Delta \ln (\mathrm{REX})$ & 0.0619 \\
\hline$\Delta \ln \left(Y^{w}\right)$ & $3.1020 * * *$ & $\Delta \ln \left(Y^{w}\right)$ & $6.9404 * * *$ \\
\hline Intercept & -0.1951 & Intercept & 0.1251 \\
\hline France & & UK & \\
\hline Long-Run & & Long-Run & \\
\hline $\ln (\mathrm{REX})$ & $-2.0405^{* * *}$ & $\ln (R E X)$ & -0.1159 \\
\hline $\ln \left(Y^{w}\right)$ & $1.0052 * * *$ & $\ln \left(Y^{w}\right)$ & $1.4688 * * *$ \\
\hline Short-Run & & Short-Run & \\
\hline Error correction term & $-0.0764 * *$ & Error correction term & $-0.0990 *$ \\
\hline$\Delta \ln (\mathrm{REX})$ & $-0.2626 *$ & $\Delta \ln (\mathrm{REX})$ & $-0.2270 *$ \\
\hline$\Delta \ln \left(Y^{w}\right)$ & $3.0248 * * *$ & $\Delta \ln \left(Y^{w}\right)$ & $3.9665^{* * *}$ \\
\hline Intercept & $0.6982 * *$ & Intercept & -0.1837 \\
\hline Germany & & USA & \\
\hline Long-Run & & Long-Run & \\
\hline $\ln (\mathrm{REX})$ & $-0.6702 * * *$ & $\ln (\mathrm{REX})$ & -1.7666 \\
\hline $\ln \left(Y^{w}\right)$ & $2.0309 * * *$ & $\ln \left(Y^{w}\right)$ & $1.3541 * * *$ \\
\hline Short-Run & & Short-Run & \\
\hline Error correction term & $-0.3287 * * *$ & Error correction term & -0.0502 \\
\hline$\Delta \ln (\mathrm{REX})$ & 0.1100 & $\Delta \ln (\mathrm{REX})$ & $-0.1921 *$ \\
\hline$\Delta \ln \left(\mathrm{Y}^{\mathrm{w}}\right)$ & $3.0716 * * *$ & $\Delta \ln \left(Y^{W}\right)$ & $2.6022 * * *$ \\
\hline Intercept & -0.5654 & Intercept & $0.3195^{*}$ \\
\hline \multicolumn{4}{|l|}{ Italy } \\
\hline \multicolumn{4}{|l|}{ Long-Run } \\
\hline $\ln (\mathrm{REX})$ & $-0.7249 * * *$ & & \\
\hline $\ln \left(Y^{w}\right)$ & $0.9768^{* * *}$ & & \\
\hline \multicolumn{4}{|l|}{ Short-Run } \\
\hline Error correction term & $-0.1218 * * *$ & & \\
\hline$\Delta \ln (\mathrm{REX})$ & $-0.3283 * * *$ & & \\
\hline$\Delta \ln \left(Y^{w}\right)$ & $4.0579 * * *$ & & \\
\hline Intercept & $0.3950 *$ & & \\
\hline
\end{tabular}

Obs.$=616$; Number of Groups $=7$; Obs. per Group $=88$

Signif. codes: '***' 0.001 '**' 0.01 ' *' 0.05 '? 0.1 ' ' 1 


\section{References}

Abadie, A. and Gardeazabal, J. (2003) "The Economic Cost of Conflict: a Case Study of the Basque Country", American Economic Review, Vol.93, pp.113-132

Algieri B. (2011), Modelling export equations using an unobserved component model: the case of the Euro Area and its competitors, Empirical Economics, Vol.41, pp.593-637

Anaraki, N., K., (2014) Effects of EURO devaluation on Eurozone Exports, International Journal of Economics and Finance, Vol.6, pp.19-24

Anderton, R. (1991), Underlying trends in manufacturing export shares for six major industrialized countries, Bull Econ Res 43(2), pp.169-178

Bahmani-Oskooee, M., \& Brooks, T. J. (1999). Bilateral J-curve between US and her trading partners. Review of World Economics, 135(1), 156-165

Bahmani-Oskooee M. and Niroomand F., (1998), Long-run elasticities and the Marshall-Lerner condition revisited, Economic Letters, Vol.61, pp.101-109

Baltagi, B. H. (2008). Econometric Analysis of Panel Data ( $4^{\text {th }}$ ed.). New York: John Wiley and Sons

Bayoumi, T., Harmsen, R. T. and Turunen, J. (2011). Euro-area export performance and competitiveness, IMF Working Papers, Washington DC

Bodegan, C., Kraemer, B. and Maucher, M. (2010) "The changing labour market in Germany in time of crises", WP19, Institute of Economic and Social Research, Hans-KöcklerFoundation

Bonham, C. S. et al. (2013), Estimating Demand Elasticities in Non-Stationary Panels: The Case of Hawaii Tourism. Working Paper-University of Hawaii Economic Research Organization, University of Hawaii at Manoa

Borey, G., and Quille, B. (2013) How to explain the recent shift in balance-of-trade trends in Europe ?, Special Analysis/July2013, National Institute for Statistics and Economic Studies, Paris

Caporale G.M. and Chui M.K.F. (1999) Estimating income and price elasticities of trade in a cointegration framework, Review of International Economics, Vol.7, pp.192-202

Chen, R., Milesi-Ferretti, G.M. and Tressel, T. (2012) "External Imbalances in the Euro Area", IMF Working Paper12/236, Washington DC

Chinn, M. D. (2004). Incomes, Exchange Rates and the US Trade Deficit, Once Again*. International Finance, 7(3), 451-469

Crane, L., Crowley, M. A. and Quayyum, S. (2007) Understanding the evolution of trade deficits: Trade elasticities of industrialized countries, Federal Reserve Bank of Chicago Economic Perspectives 4Q/2007: 2-17

Dezeure, N. and Teixeira, B. (2014) Why are British exports so weak?, Flash Economics, Vol.31, pp.1-11

Eberhardt M. (2011) Panel time-series modelling: New tools for analyzing xt data, United Kingdom Stata Users' Group Meetings 2011

Gagnon, J. E. (2013). Currency Wars, The Milken Institute Review, pp.47-55

Goldstein, M. and Khan, M. S. (1985), "Income and price effects in foreign trade", in: Jones R. W., Kenen P. B., eds, Handbook of International Economics, Amsterdam, North Holland

Gregory, A.W. and Hansen, B.E. (1996), Residual-based tests for co-integration in models with regime shifts, Journal of Econometrics, Vol.70, pp.99-126

GriGor'ev, L. and Salikhov, M. (2009) "Financial Crisis 2008. Entering Global Recession", Problems of Economic Transition, Vol.51, pp.35-62

Hamori S. and Yin F. (2011), Estimating the import demand function in the autoregressive distributed lag framework: the case of China, Economics Bulletin, Vol.31, pp.1576-91 
Hooper P., Johnson K., Marquez J. (1998), Trade elasticities for G-7 countries. International Finance discussion papers, no. 609Hooper P., Johnson K., Marquez J. (2000), Trade elasticities for the G-7 Countries, Princeton Studies in International economics, no. 87

Houthakker, H. S. and Magee, S. P. (1969) Income and price elasticities in world trade, The Review of Economics and Statistics, Vol.51, pp.111-25

Hsiao (2007) Panel data analysis-advantages and challenges, Sociedad de Estadística e Investigación Operativa

Im K.S, Pesaran M.H., Shin Y. (2003) Testing for Unit Roots in Heterogeneous Panels, Journal of Econometrics, Vol. 115, pp. 53-74

Jacobi, L. and Kluve, J. (2006) Before and After the Hartz Reforms: the Performance of Active Labour Market Policy in Germany, WPN.2100, IZA Institute, Germany

Johansen, S. (1991) Estimation and hypothesis testing of cointegration vectors in Gaussian vector autoregressive models. Econometrica: Journal of the Econometric Society, 1551-1580

Jovanovic, B. (2012) Estimating Trade Elasticities for Ex Socialist Countries: The Case of Macedonia, National Bank of the Republic of Macedonia, 2012

Joyce, M., Lasaosa, A., Stevens, I., and Tong, M. (2011) The financial market impact of quantitative easing in the United Kingdom, International Journal of Central Banking, Vol.7, pp.113-161

Kerr, W. A. and Hobbs, A.L. (2001) Taming the Dragon: The WTO After the Accession of China", Estey Centre Journal of International Law and Trade Policy, Vol.2, N.1

Ketenci N. and Uz I., (2011), Bilateral and regional trade elasticities of the EU, Empirical Economics, Vol.40, pp.839-854

Komoto G. and Thorbecke W. (2010) Investigating the Effect of Exchange Rate Changes on Transpacific Rebalancing, ADBI Working Paper Series No. 2010/247

Kravis, I. and Lipsey, R. (1978) "Price behaviour in the light of balance of payments theories", Journal of International Economics, Vol.8, pp.193-246

Kubota, M. (2009), Real exchange rate misalignments: theoretical modelling and empirical evidence. Discussion Papers in Economics. York: University of York

Levin, A., Lin, C. F., and James Chu, C. S. (2002) Unit root tests in panel data: asymptotic and finite-sample properties, Journal of Econometrics, Vol.108, pp.1-24

Macis, M. and Schivardi, F. (2012) Exports and Wages: Rent Sharing, Workforce Composition or Returns to Skills?, Discussion Papers \#6466, IZA Institute, Germany

MacKinnon J. G. (2010) Critical Values for Co-integration Tests, Queen's Economics Department Working Paper, N. 1227, Queen's University, Canada

Mann, C. L. (2002). Perspectives on the US current account deficit and sustainability. Journal of Economic Perspectives, 131-152.

Marquez J. (1999), Long-period trade elasticities for Canada, Japan, and the United States, Review of International Economics, 7 (1), pp. 102-116Orcutt G. H. (1950) Measurement of price elasticities in International trade, The Review of Economics and Statistics, Vol.32, pp.117132

Pesaran, M.H., Smith, Y. and Im, K.S. (1996) Dynamic Linear Models for Heterogeneous Panels in László Mátyás, Patrick Sevestre, eds, The Econometrics of Panel Data. A Handbook of the Theory with Applications, Springer, Netherlands

Pesaran, M.H., Shin, Y. and Smith R.P. (1999) Pooled Mean Group Estimation of Dynamic Heterogeneous Panel, Journal of the American Statistical Association, Vol.94, pp.621-634

Podestà F. (2002) Recent developments in quantitative comparative methodology: The case of pooled time series cross-section analysis, DSS Papers Soc., 3-02

Roudet S., Saxeggard M, and Tsangarides C.G. (2007) Estimation of equilibrium exchange rates in the WAEMU: a robustness analysis, IMF-WP-07/194. Washington-DC

Sawyer, W. C. and Sprinkle R. L. (1996), The demand for imports and exports in the U.S.: a survey" Journal of Economics and Finance, Vol. 20, pp.147-178 
Senhadji A. S. and Montenegro C. E. (1999), Time-series Analysis of Export Demand Equations: a Cross-Country Analysis, IMF Staff Papers, Washington DC

Shigeyuki H. and Yoichi M. (2009) Empirical Analysis of Export Demand Behavior of LDCs: Panel Co-integration Approach, Kobe University MPRA Paper, No.17316

Stern, R. M., Francis, J. and Schumacher, B. (1976) Price elasticities in international trade: An annotated bibliography, London: Macmillan for the Trade Policy Research Centre, London

Thorbecke W. (2011) Investigating the effect of exchange rate on China's processed exports, Journal of the Japanese and International Economics, Vol.25, pp.33-46

Thorbecke, W. and Kato, A. (2012) The effect of exchange rate changes on Japanese consumption exports, Japan and the World Economy, Vol.24, pp.64-71

Westerlund, J. (2007) Testing for error correction in panel data. Oxford Bulletin of Economics and Statistics, Vol.69, pp.709-748

Wren-Lewis, S., \& Driver, R. (1998). Real exchange rates for the year 2000.Peterson Institute Press: Policy Analyses in International Economics

Yao, Z., Tian, F. and Su, Q. (2013) Income and Price Elasticities of China's Exports, China \& World Economy, Vol.21, pp.91-106 